http://dx.doi.org/10.4314/jae.v17i1.4

\title{
Risk management strategies utilized by small scale poultry farmers in Oyo State, Nigeria: Implications for agricultural transformation
}

\author{
Akinbile, Luqman. A., Akinpelu, Olutoyin. M., "Akwiwu, Uzoamaka. N. \\ Department of Agricultural Extension and Rural Development \\ Faculty of Agriculture and Forestry \\ University of Ibadan \\ `Email: uzoakwiwu@yahoo.co.uk, 08037783241.
}

\begin{abstract}
Birds can only tolerate narrow temperature changes; therefore, poultry flocks are vulnerable to climate induced risk. This study investigated risk management strategies utilized by small scale poultry farmers in Oyo state. A total of 118 respondents were sampled using multi stage sampling procedure. Interview schedule was used to elicit perception of climate change related on risks, utilization of available climate change information and management strategies employed for risk reduction. Data were described using frequency counts and percentages. PPMC, Chi-square analysis, Independent t-test and multiple linear regression analysis were used to test hypotheses. Majority (58.5\%) of the respondents were aged between 31 to 50 years ( = 40.38 \pm 10.96 years), were males $(77.1 \%$ ), had high level of education (74.3\%), with mean farming experience and estimated monthly income of 10 years and $\mathrm{A330,000}$ respectively. Utilization of climate information was high (53.4\%) among the small scale poultry farmers who had access to information. Most (55.1\%) of the respondents had a high risk perception of climate change. Production risks were the most experienced in relation to climate change. Management practices were high among the respondents (61.9\%) and mostly employed in cases of production risks. A negative correlation existed between climate risk perception of farmers and the management strategies employed ( $r=-$ 0.413), while utilization of climate change information directly correlated with the management strategies employed $(r=0.281)$. Significant difference existed between climate risk management strategies employed by members and non-members of $P A N$ in Oyo State ( $t=2.49)$. Major predictors of risk management strategies employed by farmers were: production risks, utilization of climate information and financial risks, respectively $\left(R^{2}=0.344\right)$. The study concluded that the level of risk perception was high among small scale poultry farmers in Oyo State, thus, the high level of management strategy used.
\end{abstract}

\section{Introduction}

Climate change is undoubtedly the most current and topical global environmental issue. This is because apart from being environmental, it also has developmental dimension. Climate is the synthesis of weather of a given area or location over a period of at least thirty years. Its elements include the atmosphere, lithosphere, hydrosphere, cryosphere and the biosphere, all interacting together and powered by solar radiation. Disturbances to the steady state of the climate system bring about movement over time to a new state of equilibrium i.e. a new climate state and this 
has a permanent effect on the ecosystem and the environment until another change occurs (Ayoade, 2010).

African nations and indeed developing countries including Nigeria suffer most from climate change consequences because of high dependence on agriculture carried out on large expanse of arid or semi-arid cultivable lands which is climate sensitive.

According to Akinbile (2010), estimate of the effects of climate change on crop yields are predominantly negative for the tropics. The possible effects of climate change on food production is not only limited to crops in agriculture, but also has far reaching consequence on poultry, livestock and fisheries sub sector. As observed by Adene and Oguntade, 2006, the poultry sub-sector is the most common of all the subsectors of Nigeria's agriculture. The types of poultry that are commonly reared in Nigeria are chickens, ducks, guinea fowls, turkeys and pigeons. Those that are of commercial or economic importance given the trade in poultry, however, are chickens, guinea fowls and turkeys, amongst which chickens predominate.

Local communities and indigenous peoples have an in-depth understanding of their environment and a vast experience in managing climate variability. This knowledge is key to the development of effective adaptation strategies (Calviosa et.al, 2009). It is of importance to note that climate risks are location specific, differing across geographic zones. The likely impacts of climate change on agriculture are regionally and highly distinct (Rowlinson, 2008). Therefore responses to variations (adaptive capacity) are expected to differ across locations and are expected to be influenced by individual risk perceptions and several intervening variables such as socioeconomic status, environmental conditions and resources available to farmers.

Sustainability and performance of poultry farm infrastructure is highly compromised as a result of extreme weather such as flood, high temperatures and susceptibility to heat stress. This manifests as reduced feed intake, reduced laying performance, reduced fertility level, decreased activity, in the worst cases increased mortality. These factors are some of the factors that contribute to under-performance of investment in the poultry enterprise.

In this regard, climate risks pose enormous challenges to the possible contributions of poultry towards the attainment of the Millennium Development Goals of addressing the problem of extreme poverty in its many dimensions. It also poses a threat to the realization of the nation's Agricultural Transformation Agenda (ATA). In their work, Thornton et. al. (2008) observe that there are considerable gaps in knowledge of how climate change and increasing climate variability will affect livestock systems and the livelihoods of the people who depend on them. They also highlight the need for detailed assessment of localized impacts, and the importance of identifying appropriate options that can help livestock keepers adapt to climate change. Limited availability of reliable and useful information on climate risks and management is usually an obstacle in this regard. While affecting all economic sectors, climate risks to individual industries will differ in dimension and extent. In view of this, small scale poultry farmers need to consider management options to help avoid, reduce, control or transfer risks, cost and concern in the future. It is therefore important that the nature and extent of their adaptation to climate-related risks is examined.

\section{Objectives}


1.) determine the risk perceptions of the poultry farmers about climate change and variability;

2.) ascertain utilization of available climate information by the small scale poultry farmers;

3.) determine management strategies employed by the small scale poultry farmers for risk reduction in the study area.

\section{Hypotheses}

1.) There is no significant relationship between risk perception and management strategies employed among the poultry farmers.

2.) There is no significant relationship between utilization of climate information and climate risk management strategies employed by the poultry farmers.

3.) There is no significant difference in climate risk management strategies employed by members and non-members of Poultry Association of Nigeria (PAN), Oyo State branch.

4.) There is no significant contribution of type of risk to which they are exposed, knowledge of climate risk, availability, access and use of climate information to risk management strategies employed by the poultry farmers.

\section{Methodology}

The study was carried out in Oyo state of Nigeria. The population of the study consisted of all small scale poultry farmers, including those who were registered with and those not registered with the Poultry Association of Nigeria (PAN) in Oyo State. A multi-stage sampling procedure was employed. Small scale poultry farmers were stratified into; registered members of PAN in Oyo State and non-members of PAN. Thirty percent of the 195 currently registered with PAN were randomly selected. This gave 59 respondents. A list of equivalent number of non-members of PAN (i.e. 195) was also generated by snowball technique and 30\% (i.e. 59) of these were again randomly selected. Therefore, a total number of 118 respondents were interviewed. Data was collected from primary sources, using a valid and reliable interview schedule. A scale of risk perception was adapted from the Domain-Specific Risk Taking Scale (DOSPERT) (Weber, 2003) to measure farmers' risk perception to climate change. Respondents were asked to respond appropriately to a list of perception statements to indicate how risky they perceive a variety of climate situations; They were scored on a five point risk scale of not at all risky (1), moderately risky (2), risky (3), very risky (4), and extremely risky (5). Aggregated scores on the indicators of risk perception provided a basis for classification of farmers' risk perception into high or low categories. Respondents were required to state their level of utilization of climate information on different risk categories. This was measured on a four point scale of never utilized $=0$, sometimes utilized $=1$, mostly utilized $=2$ and always utilized $=3$. Identified and listed risk categories are production, marketing, financial, human and legal/institutional risks.

Respondents were asked to indicate management strategies they employ to tackle risky situations from a list of sixteen (16) strategies with respect to the types of climate risks. The listed strategies were broadly categorized as; avoidance measures, control measures, reduction measures, transfer measures and disaster 
risk management. A score of 1 was assigned to each management strategy used. Hence an index of risk management strategies was obtained and the mean score was used to categorise the respondents into high(above mean) and low (below mean). Data were described using frequency counts and percentages. PPMC, Chisquare analysis, Independent t-test and multiple linear regression analysis were used to test hypotheses.

\section{Result and discussion}

\section{Distribution of respondents according to their socio-economic characteristics}

Majority (58.5\%) of the respondents fell within the age range of $31-50$ years with a mean age of 40.3 years. This is an indication that majority of the poultry farmers are still actively involved in farming activities. Hence, they are economically productive. According to Zhang and Flick (2001), age determines the level of involvement of farmers in farming activities. Majority of the poultry farmers were male $(77.1 \%)$. This suggests that women were less involved in farming activities, and so involved in offfarm activities than their male counterparts. This is in consonance with the report from FAO (2001) that women were more involved in off-farm activities than men, especially transportation of farm produce, processing of farm produce, feeding of family members and reproductive functions. The educational level of majority of the respondents is high, with $74.3 \%$ of the respondents having attained one form of tertiary education or the other and $6.8 \%$ of the respondents having had post graduate education. The high level of literacy among the respondents is expected to have a positive influence on their perception of climax risks and management. They are also able to source information from a variety of channels. The findings of the study also revealed that majority $(72.9 \%)$ of the respondents had stock size of between 10 and 400 birds ( $X=280.59$ ). While $14.4 \%$ have about 2000 birds.

Due to the high level of risk, involved $74.6 \%$ of the respondents owned the property on which the poultry farms were sited, while $25.4 \%$ rented, leased or the borrowed property. Measures such as relocation of farm in cases of flooding for example may be a difficult decision for farmers who own the property on which they rear poultry.

A high disparity existed between the observed minimum estimated monthly income of $\mathrm{N} 1,000$ and the maximum N20,000. This can be attributed to the farm/stock size which is also highly dispersed. According to Sarap and Vashist (1994), farm income is negatively correlated with farmers' level of risk aversion. Hence, smaller farm managers are expected to be more risk seeking than managers of large farms and this should have a positive influence on risk management. The study further reveals that only $39 \%$ of the respondents were involved in some other occupation (secondary or primary) besides poultry farming while majority $(61 \%)$ have poultry farming as their sole source of livelihood. According to Ayinde (2008), the presence of other sources of income enhances the risk bearing ability of farmers and thus reduces their level of risk management. 
Table1

Personal characteristics of respondents

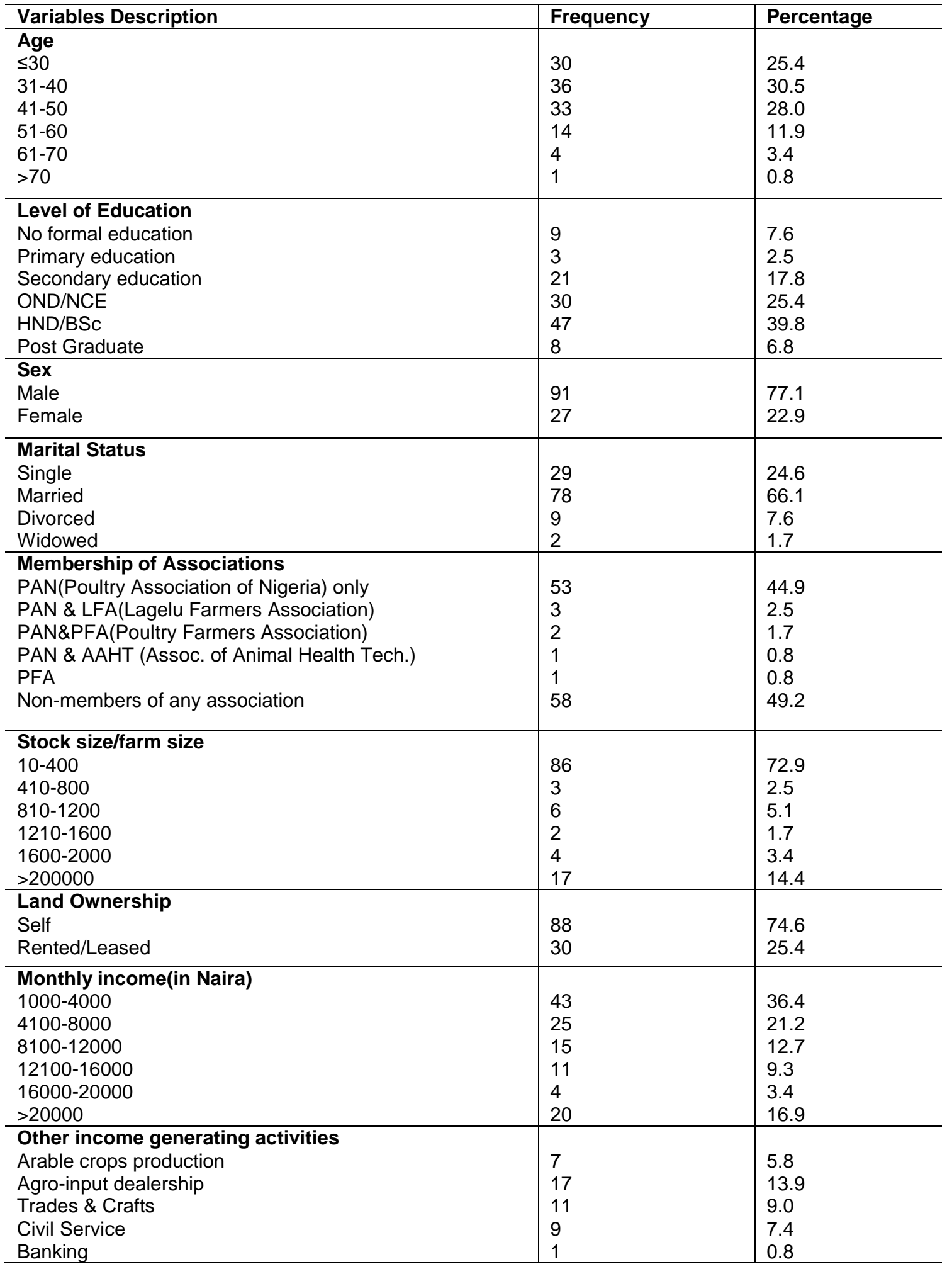

\section{Respondents' risk perception of climate change}

Vaccination failure ( $\bar{X}=3.76)$, scarcity of water $(\bar{X}=3.69)$ and scarcity of feed ( $\bar{X}=3.63$ ) were mostly perceived as extremely risky by the respondents, while 
climate change resulting in relocation of farm ( $\bar{X}=2.50)$ and laying off staff ( $\bar{X}=2.63$ ) were perceived as the least threat of climate change to poultry production.(Table 2) This may explain why the risk perception of climate change is low among the farmers as people tend not to admit a risky situation until live(s) or sources of livelihood are threatened.

\section{Table 2}

Distribution of respondents based on their risk perceptions of climate change effects

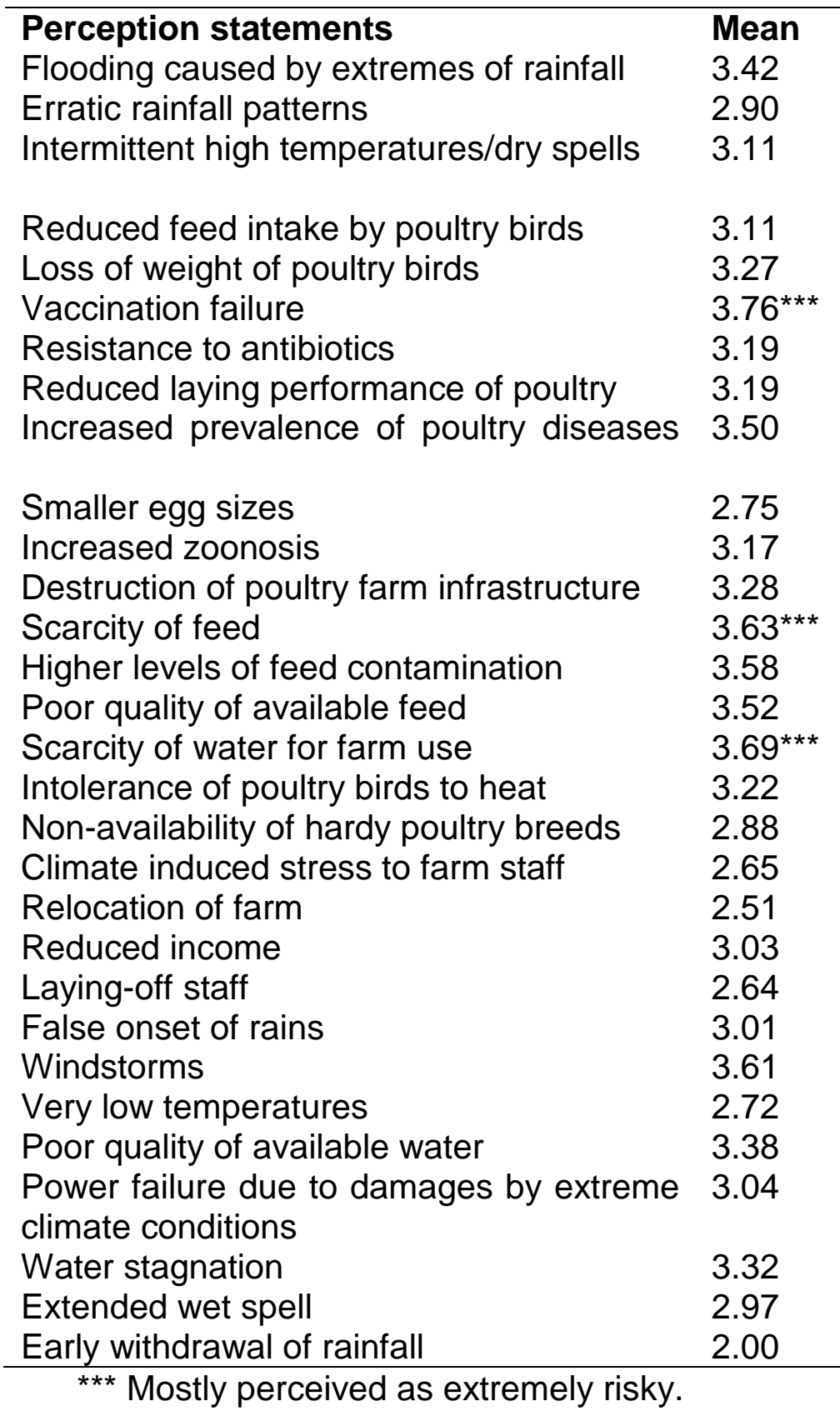

Distribution of respondents according to their level of risk perception of climate change effects

Majority (55.1\%) of the respondents had high risk perception of climate change impacts, while $44.9 \%$ of them have low risk perception of impacts of climate change 
Table 3. The percentage of respondents who still do not perceive climate change as risky is worrisome, considering their risk exposure and vulnerability to it. Therefore there is an urgent need to intensify actions to improve how farmers perceive the effects of climate change.

Table 3

Distribution of respondents according to their level of risk perception of climate change effects

\begin{tabular}{lccccc}
\hline Scores & Frequency & Percentage & Minimum & Maximum & Mean \\
Low & 53 & 44.9 & 38.00 & 150.00 & 95.0678 \\
$(38-95.2)$ & & & & & \\
$\begin{array}{l}\text { High } \\
(95.3-150)\end{array}$ & 65 & 55.1 & & & \\
Total & 118 & 100 & & & \\
\hline
\end{tabular}

Respondents' utilization of climate change information with respect to climate risks

Table 4 reveal that information about climate risks with respect to production ( $\bar{X}=1.71$ ) and marketing $(\bar{X}=1.70)$ were mostly utilized by the respondents. This implies that level of production and effective marketing channel are likely to improve standard of living than others.

Table 4

Distribution of respondents based on utilization of climate change information

\begin{tabular}{|c|c|c|}
\hline & Climate risk information & Mean \\
\hline \multicolumn{3}{|c|}{$\mathrm{S} / \mathrm{N}$} \\
\hline 1 & $\begin{array}{l}\text { Information on climate risks as it affects } \\
\text { production. }\end{array}$ & $1.71^{\star \star *}$ \\
\hline 2 & Information on climate risks to marketing. & $1.70^{* * *}$ \\
\hline 3 & $\begin{array}{l}\text { Information on financial aids in managing } \\
\text { climate risks (insurance packages, } \\
\text { available credit sources). }\end{array}$ & 1.51 \\
\hline 4 & Information on climate risks to humans & $1.58^{* * *}$ \\
\hline 5 & $\begin{array}{l}\text { Information on legal/institutional risk as a } \\
\text { result of climate variation/variation. }\end{array}$ & 1.44 \\
\hline
\end{tabular}

Distribution of respondents based on level of utilization of climate information for management strategies.

The results reveal that $53.4 \%$ of the respondents have a high level of utilization of climate change information while $46.6 \%$ of them utilized climate change information at low levels. This is an indication that the high level of education attained by most of 
the respondents aid them in accessing and consequently utilization of available information on climate change, it is also expected that it will help them to better manage climate-related risks. Information about climate change is a crucial component of knowledge, perception and adaptation. It is therefore important to motivate farmers to actively seek and use information on climate risks.

Table 5

Distribution of respondents based on level of utilization of climate information for management strategies

\begin{tabular}{lccccc}
\hline Scores & Frequency & Percentage & Minimum & Maximum & Mean \\
Low $(0-7.8)$ & 55 & 46.6 & .00 & 15.00 & 7.9492 \\
High(7.9- & 63 & 53.4 & & & \\
$\begin{array}{l}15) \\
\text { Total }\end{array}$ & $\mathbf{1 1 8}$ & $\mathbf{1 0 0}$ & & & \\
\hline
\end{tabular}

\section{Management Strategies of respondents}

Respondents' management strategies were measured against the different climate risk types. The listed management strategies are categorized as avoidance measures, preventive measures, control measures, transfer measures and disaster risk management. Results reveal that disasters risk ( $\bar{X}=.21)$, upgrading sanitary measures (control measure) $(\bar{X}=.20)$ and increased water use efficiency (sanitary measures) ( $\bar{X}=.19)$ were the most employed management strategies by the respondents. This result suggests the prominence of climate risks associated with sudden disaster and poor hygiene among small scale poultry farmers. This is consistent with the argument of Thornton and Herrero (2008) who expressed that poor hygiene practices ranked as one of the most important climate associated risks confronting poultry farmers in Nigeria. 


\section{Table 6}

ISSN 1119-944X

Distribution of respondents based on management strategies employed for the risk types

\begin{tabular}{|c|c|c|c|c|c|c|}
\hline $\begin{array}{l}\text { Management } \\
\text { strategies }\end{array}$ & $\begin{array}{l}\text { Production } \\
\text { Risks } \\
\text { F(N) }\end{array}$ & $\begin{array}{l}\text { Marketing } \\
\text { Risks } \\
\text { F(N) }\end{array}$ & $\begin{array}{l}\text { Financial } \\
\text { Risks } \\
\text { F(N) }\end{array}$ & $\begin{array}{l}\text { Human } \\
\text { Risks } \\
\mathrm{F}(\mathrm{N})\end{array}$ & $\begin{array}{l}\text { Legal } \\
\text { Risks } \\
\text { F(N) }\end{array}$ & Mean \\
\hline \multicolumn{7}{|l|}{ Avoidance Measures } \\
\hline Hardy/tolerant breeds & $55.9(66)$ & $11.9(14)$ & $11.9(14)$ & $10.2(12)$ & $3.4(4)$ & .10 \\
\hline Divers & 2 & $9.0(46)$ & 30.5 & 4. & $4.2(5)$ & .04 \\
\hline cation & & 6 & & 11 & $2.5(3)$ & .11 \\
\hline \multicolumn{7}{|l|}{ Preventive Measures } \\
\hline $\begin{array}{l}\text { Reinforcing } \\
\text { infrastructure }\end{array}$ & $35.6(42)$ & $19.5(23)$ & $33.9(40)$ & $9.3(11)$ & $8.5(10)$ & .09 \\
\hline $\begin{array}{l}\text { Improved vaccination } \\
\text { scheme }\end{array}$ & 43.2 & $3(18)$ & $27.1(32)$ & 8) & $5.9(7)$ & .07 \\
\hline Mixed farming practices & $39.8(47)$ & $17.8(21)$ & $21.2(25)$ & $15.3(18)$ & $1.7(2)$ & .15 \\
\hline Water harvesting & $38.1(45)$ & $17.8(21)$ & $15.3(18)$ & $13.6(16)$ & $4.2(5)$ & .14 \\
\hline $\begin{array}{l}\text { Replacing stock with } \\
\text { more hardy breeds }\end{array}$ & 37.3 & 16.1(19) & $28.8(34)$ & $4.2(5)$ & $2.5(3)$ & .04 \\
\hline $\begin{array}{l}\text { Upgrading sanitary } \\
\text { measures }\end{array}$ & $27.1(32)$ & $15.3(18)$ & $18.6(22)$ & $20.3(24)$ & $4.2(5)$ & $.20^{\star \star \star}$ \\
\hline \multicolumn{7}{|l|}{ Control Measures } \\
\hline Adjusting prices & $16.9(20)$ & $31.4(37)$ & $12.7(15)$ & $5.9(7)$ & $1.7(2)$ & .05 \\
\hline $\begin{array}{l}\text { Increased water use } \\
\text { efficiency }\end{array}$ & 35.6 & $18.6(22)$ & 15.3 & $18.6(22)$ & $0.8(1)$ & $.18^{\star \star \star}$ \\
\hline Cooperative activities & $25.4(30)$ & $20.3(24)$ & $30.5(36)$ & $14.4(17)$ & $7.6(9)$ & .14 \\
\hline $\begin{array}{l}\text { Market coordination } \\
\text { Transfer Measures }\end{array}$ & $12.7(15)$ & $47.5(56)$ & $15.3(18)$ & $9.3(11)$ & $3.4(4)$ & .09 \\
\hline chemes & $16 . \varsigma$ & 16. & 34.7 & $5 . \varsigma$ & 16.1(19) & .06 \\
\hline Outsourcing/contracting & $18.6(22)$ & $16.9(20)$ & $33.9(40)$ & $19.5(23)$ & $15.3(18)$ & .19 \\
\hline $\begin{array}{l}\text { Disaster } \\
\text { management }\end{array}$ & $22.0(26)$ & $9.5(23)$ & 23.7(28) & $21.2(25)$ & $19.5(23)$ & $.21^{* * *}$ \\
\hline
\end{tabular}

${ }^{\star * \star}$ Mostly employed management strategies

Distribution of respondents based on utilization levels of management strategies for risk types.

From Table 7 It can be observed from the mean values that management strategies were most employed for production risks (4.75). Mean utilization of management strategies to resolve financial and market risk issues by the respondents are 3.89 and 3.43 respectively. Management strategies were least used to deal with human risks (1.89) legal/institutional risks (1.02). Thus, efforts to assist the farmers should focus on their production risks as they engage the attention of the farmers more than other risks. 
Table 7

Distribution of respondents based on utilization levels of management strategies

\begin{tabular}{lllllll}
\hline $\begin{array}{l}\text { Management } \\
\text { strategies } \\
\text { Production Risks }\end{array}$ & F & $\%$ & $\begin{array}{l}\text { Range of } \\
\text { Scores }\end{array}$ & Mean & Minimum & Maximum \\
$\begin{array}{l}\text { High } \\
\text { Low }\end{array}$ & 62 & 52.5 & $0-4.7$ & 4.7542 & 0.00 & 14.00 \\
$\begin{array}{l}\text { Market Risks } \\
\text { High }\end{array}$ & 56 & 47.5 & $4.8-14$ & & & \\
Low & 70 & 59.3 & $0-3.3$ & 3.4322 & 0.00 & 12.00 \\
$\begin{array}{l}\text { Financial risks } \\
\quad \text { High }\end{array}$ & 48 & 40.7 & $3.4-12$ & & & \\
$\quad$ Low & 51 & 43.2 & $0-3.8$ & 3.8983 & 0.00 & 11.00 \\
$\begin{array}{l}\text { Legal Risks } \\
\text { High }\end{array}$ & 67 & 56.8 & $3.9-11$ & & & \\
$\quad$ Low & 65 & 55.1 & $0-0.9$ & 1.0169 & 0.00 & 5.00 \\
$\quad$ Human Risks & 53 & 44.9 & $1-5$ & & & \\
$\quad$ High & & & & & & \\
$\quad$ Low & 70 & 59.3 & $0-1.8$ & 1.8983 & 0.00 & 16.00 \\
\hline
\end{tabular}

\section{Summary of respondents' management strategies}

Summarily, Mean value of 15.00 was recorded for all management strategies. $61.9 \%$ of respondents' had scores above the mean while $38.1 \%$ scored below the mean. Utilization of management strategies for climate risk issues is therefore high among the small scale poultry farmers. This finding can be attributed to respondents' educational status and utilization of useful climate information for management decisions. However, much still needs to be done to increase levels of climate risk management especially among poultry farmers.

\section{Table 8}

Distribution of respondents' level of utilization of management strategies.

Scores Frequency Percentage Minimum Maximum Mean

\begin{tabular}{lrrrrr} 
Low & 45 & 38.1 & .00 & 34.00 & 15.0000 \\
High & 73 & 61.9 & & & \\
Total & 118 & 100 & & & \\
\hline
\end{tabular}


Relationship between respondents' risk perception and management
strategies employed.

Correlation analysis results reveal negative correlation $(r=-0.413)$ in the relationship between respondents risk perception of climate change and management strategies employed, hence The stated null hypothesis is accepted. This result corroborates the findings of Anton (2008), that farmers' level of risk management is influenced by their attitude towards risks. It however deviates from the findings of Sangotegbe(2011) and Hassan \& Nhemachena (2008) that perception is an important factor influencing adaptation. It also negates the assertion of Mileti (1993), that farmers' responses to risks are often in ways consistent with their perception of risks and it is these perceptions that influence behaviours or actions. In their work, O'Connor et.al(1995) also theorized that risk perceptions of climate change and knowledge of its causes will predict individuals' preferences regarding what (if anything) should be done to address climate change.

This finding therefore can be attributed to the fact that risk perception of climate change and its consequences is low among the respondents (Table 4.3).It can therefore be inferred that low risk perception therefore resulted in low level of management strategies.

Relationship between respondents utilization of climate information and management strategies employed

The results of correlation analysis show a significant relationship between utilization of climate information and management strategies employed. Therefore, the null hypothesis is rejected, and the alternative hypothesis accepted. This result is in agreement with Jones and Henessy (2000) that the availability of better climate and agricultural information helps farmers make comparative decisions among alternative management practices and hence choose those that enable them cope better with changes in climate.

Table 9

A summary table of correlation between utilization of climate information and management strategies employed.

\begin{tabular}{lllll}
\hline Variable & & & r-value & p- value \\
\hline $\begin{array}{l}\text { Utilization of } \\
\text { information } \\
\text { Risk perception }\end{array}$ & climate & risk & 0.281 & 0.002 \\
\hline
\end{tabular}


Difference in climate risk management strategies employed by members and non-members of Poultry Association of Nigeria (PAN), Oyo State branch.

Independent t-test result reveal that there exists significant difference $(p<0.05)$ in climate risk management strategies employed members and non-members of Poultry Association of Nigeria (PAN), Oyo State branch. The null hypothesis is therefore rejected in favour of the alternative hypothesis. Farmers' inclination towards social networks is therefore a positive influence on their level of risk management as they are able to share information with one another. This is similar to the observations of Aye and Oji (2005) while studying crop farmers that membership of a solidarity group enhances farmers' access to credit and other production inputs-such as fertilizer, chemicals and improved seeds.

Table 10

Summary table of test of difference between members and non-members

\begin{tabular}{llllll|l|l|}
\hline Category & N & Mean & S.D & S.E & T & df & \multicolumn{1}{l}{ P } \\
\hline Members & 59 & 16.25 & 3.452 & 0.450 & 2.49 & 116 & 0.014 \\
\hline $\begin{array}{l}\text { Non- } \\
\text { members }\end{array}$ & 59 & 13.75 & 6.905 & 0.899 & & & \\
\hline
\end{tabular}

There is no significant contribution of type of risk to which they are exposed, availability and use of climate information to risk management strategies employed by the poultry farmers.

\section{Contributions of the independent variables to risk management strategies of the respondents.}

Regression analysis was conducted on the variables first, to determine the contributions (joint) of each of selected independent variables and risk perception to management strategies employed by the small scale poultry farmers (Table 11). The results yielded a $R^{2}$ value of 0.344 revealing that the variables in the regression model put together explain $34.4 \%$ of the variance in farmers' utilization of management strategies for climate risks.

Individual contributions of the independent variables to management strategies employed by the respondents are shown in (Table 11). The independent variables of interest were: utilization of climate information and type of risk (production, financial, market, human and institutional).

The table further shows that four (4) of the variables significantly predicted the farmers choice of risk management strategy, these are production risk $(\beta=0.296)$, utilization of climate information $(\beta=0.251)$, and financial risks $(\beta=0.194)$ respectively. All these predictors had direct relationships to the management strategy employed by the small scale poultry farmers. The most important predictor was therefore found to be production risks. Production risks include variations in crop yields/ livestock production due to weather conditions (such as excessive rainfall and drought), diseases and pests, inefficient production techniques among others. All these pose a threat to farmers' livelihood and food security and therefore may 
require positively drastic measures to manage such. Salimonu and Falusi (2009) also asserted that risk management therefore, becomes an essential aspect of the farming business.

Table 11

Individual Contributions of variables in regression equation to Risk Management Strategies

\begin{tabular}{lccc}
\hline Variables & Beta & T & Sig. \\
Utilisation of climate & 0.251 & 2.934 & $.004^{\star \star *}$ \\
Variation information & & & \\
Production risks & 0.296 & 2.999 & $0.003^{\star \star * *}$ \\
Market risks & -0.064 & -.671 & 0.504 \\
Financial risk & 0.194 & 2.005 & $0.047^{\star}$ \\
Human Risk & -0.138 & -1.277 & 0.204 \\
Institutional Risk & 0.115 & 1.320 & 0.190 \\
& & & \\
\hline
\end{tabular}

${ }^{*}$ Significant

$R=0.587 ; R^{2}=0.344 ;$ Adjusted $R=0.296 ; S . E=4.70$.

\section{Conclusion}

The small scale poultry farmers in Oyo state were mostly male, young, married, had high level of education and low stock size. Utilization of climate information was high among the poultry farmers and management strategy practices were high among the respondents with the strategies being mostly employed in cases of production risk.

Correlations were found between respondents' climate risk perception and management strategies (negative) and utilization of climate change information and management strategies (positive). Differences exist in climate risk management employed by members and non-members of PAN in Oyo State. It was further established in the study that utilization of useful climate information by farmers and experiences with production and financial risks contributed to adoption of climate risk management strategies.

\section{References}

Akinbile, L.A. (2010). Climate change and its implications for sustainable development in Nigeria. Keynote Address at the Annual Conference of School of Agriculture and technology, federal college of Education, katsina. 20 pp.

Aye, G.C. and K.O. Oji (2007). Effects of poverty on risk attitudes of farmers in Benue State, Nigeria $12^{\text {th }}$ Annual Conference on economic modeling for Africa. $4^{\text {th }}-6^{\text {th }}$ July, Cape Town SA.

Ayinde O.E., O.E. Akanbi and O.A. Omotesho (2008) Efficiency Differentials of Government and Non-government Assisted Rice Farms: A case study of Kwara State, Nigeria. World Rural Observation 4(3), pp. 2-3

Ayoade, J.O. (2010). Climate Change: Causes, effects and solutions. Impact of climate change on food security in Sub-Saharan Africa. Proceedings of the $14^{\text {th }}$ Annual Symposium of the International Association of Research Scholars and Fellows, IITA, Ibadan (25 $5^{\text {th }}$ February) pp. 7-9. 
Calviosa, C.D. Chuluunbaatar and F. Katiuscia, IFAD (2009). Tools for project design: Livestock Thematic Paper. IFAD 5-8. Retrieved Mar. 5, 2012 from http://www.ifad.org//rkm/index.htm.

Hassan, R. \& Nhemachena, C. (2008) Determinants of climate adaptation strategies of African farmers: Multinomial choice analysis. African Journal of Agricultural and Resource Economics 2(1), 83-104.

Jones, R.N. and Hennessy, K.J. (2000). Climate change impacts in the Hunter Valley: a risk assessment of heat stress affecting dairy cattle, CSIRO Atmospheric Research Aspendale, Victoria, Australia. July. Pp15-16.

Mileti, D. (1993). Disasters by Design, A reassessment of Natural Hazards in the United States. Washington D.C: Joseph Henry Press.

O'Connor R.R., R.J. Bord and Fisher, A. (1999) Risk Perceptions, General Environmental Beliefs and Willingness to Address Climate Change. Risk Analysis vol. 19, No. 3,pp 243

Rowlinson, P., (2008) Adapting Livestock Production Systems to Climate ChangeTemperate Zones. Proceedings of the Livestock and Global Change Conference. May 2008, Tunisia.

Salimonu, K.K. and A.O. Falusi (2009). Sources of Risk and Management Strategies among Food Crop Farmers in Osun State, Nigeria. African Journal of Food Agriculture, Nutrition and Development. Vol. 9(7) http://www.ajfand.net/issue28/PDFs/Kabir8030.pdf.

Sangotegbe, N. S. (2011) Adaptation Strategies to Climate Change by Food Crop Farmers in Oke-Ogun Area of Oyo state. An unpublished thesis in the Department of Agricultural Extension and Rural Development, University of Ibadan, Nigeria. 105pp.

Thornton, P. and M., Herrero 2008. Climate Change, Vulnerability and Livestock Keepers: Challenges for Poverty Alleviation. Proceedings of the Livestock and Global Climate Change Conference. May 2008, Tunisia.

Weber, E.U., Blais A.R and Betz N. (2002). A domain specific risk attitude scale: measuring risk perception and risk behaviours. Journal of Behavioural decision making, pp263-290

Zhang, D. and W. Flick (2001). Sticks, Carrots and Reforestation Investment. Land Economics 77(3), 443-56. 